\title{
Productivity test
}

Written by: OECD

Last update: 23 January 2020

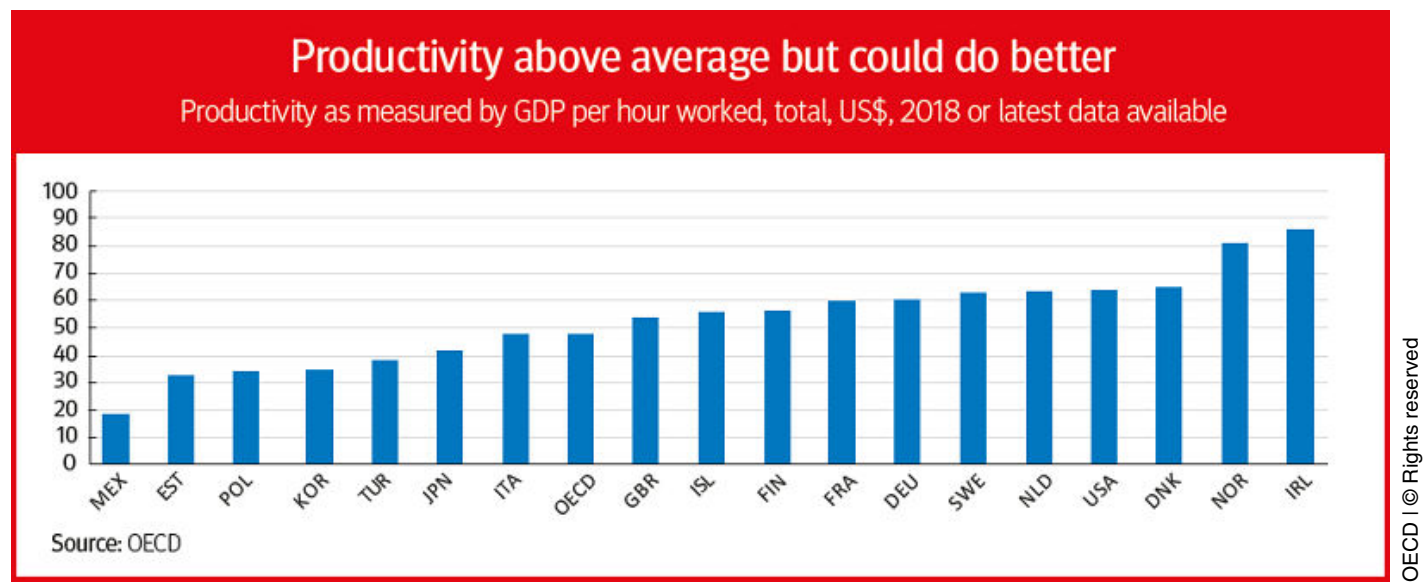

Productivity test

Finland may be top of the class for education, but it shines less brightly when it comes to productivity, even if output per hour worked is $15 \%$ above the OECD average. In fact, productivity growth has slipped back since the financial crisis a decade ago.

Relatively weak overall productivity growth partly reflects a decline in manufacturing, in particular of dynamic gazelle firms in information technology and communications equipment, for instance. Moreover, productivity in the expanding service sector is generally weaker than in manufacturing.

Beyond changes in the structure of the economy, weakening productivity growth within particular sectors has also contributed to sluggish overall productivity, with disappointing performances even among the best Finnish firms. Productivity has declined in public administration, education, social and health services, although this should be interpreted with caution given measurement issues. Also, recent increases in the employment rate, while beneficial, were concentrated among less skilled hires. Finland now has lower productivity than in the other Nordics.

Recent and planned reforms could improve competition and lift productivity, the 2018 OECD Economic Survey of Finland notes.

Digitalisation offers further opportunities, too, though there is some concern that this productivity growth will become more concentrated in a small number of 
(possibly smaller) high performing firms. Still, maintaining strong R\&D investment could also foster innovation, which if diffused, can lift productivity growth more widely.

This Databank is part of a series of articles celebrating Finland's 50th anniversary as a member country of the OECD: www.oecdobserver.org/finland50oecd COECD Observer January 2019 